(C) The Author(s), 2021. Published by Cambridge University Press for the Arizona Board of Regents on behalf of the University of Arizona. This is an Open Access article, distributed under the terms of the Creative Commons Attribution licence (http://creativecommons.org/licenses/by/4.0/), which permits unrestricted re-use, distribution, and reproduction in any medium, provided the original work is properly cited.

\title{
HAZOR EB III CITY ABANDONMENT AND IBA PEOPLE RETURN: RADIOCARBON CHRONOLOGY AND ITS IMPLICATIONS
}

\author{
Ron Lev $^{1}\left([) \cdot\right.$ Shlomit Bechar ${ }^{2,3} \cdot$ Elisabetta Boaretto $^{1 *}$ (1) \\ ${ }^{1}$ D-REAMS Radiocarbon Laboratory, Scientific Archaeology Unit, Weizmann Institute of Science, Rehovot, Israel \\ ${ }^{2}$ The Haifa Center of Mediterranean History, University of Haifa, Israel \\ ${ }^{3}$ The Hebrew University of Jerusalem, Israel
}

\begin{abstract}
Tel Hazor is one of only a few sites in Israel where remains of the Intermediate Bronze Age (IBA) in the second half of the 3rd millennium BC were found on top of Early Bronze III (EB III) city remains. A probe excavation was held at Hazor in 2017 to explore the chronological relation between the EB III and the IBA occupation. The radiocarbon $\left({ }^{14} \mathrm{C}\right)$ absolute dates generated from this probe excavation show that following the EB III city demise, the site was abandoned for up to a few hundred years before it was resettled in the IBA. ${ }^{14} \mathrm{C}$ dates obtained from the last level of the EB III city are well before $2500 \mathrm{BCE}$, fully aligned with the recent "High Chronology" for the EBA in the southern Levant. The excavation also produced dates associated with IBA "Black Wheel-Made Ware" vessels, which were found in large numbers at Hazor.
\end{abstract}

KEYWORDS: Black Wheel-Made Ware, Early Bronze III, Early Bronze IV, Hazor, Intermediate Bronze, radiocarbon.

\section{INTRODUCTION}

The Intermediate Bronze Age culture (IBA hereafter, but also known as EB IV) occupied the southern Levant in the second half of the third millennium BCE. The IBA is accepted by scholars as a non-urban pastoral-rural culture, with clear differentiation in settlement patterns, material culture, and burial habits, from the urban Early Bronze culture (EB hereafter) preceding it, and from the urban Middle Bronze culture (MB hereafter) following it. An abundance of burial sites, each including up to a few hundred burials, characterize the IBA (e.g., Oren 1973; Dever 1975; Yannai 2016). IBA settlements are mainly unfortified villages established on a new unexploited land (e.g., Smithline 2002; Eisenberg 2012; Dever 2014; Covello-Paran 2020). Exceptions are cases of IBA remains which were built on EB settlement ruins (e.g., Mazar 2006), a few walled settlements (e.g., Bar et al. 2013), and also a few IBA sites in Transjordan utilizing the EB III city architecture as their base, thus displaying local continuity (e.g., Richard 2010). Our knowledge of the IBA has been much enhanced during the last decade (D'Andrea 2014; Dever 2014; Falconer and Fall 2019; Richard 2020). Yet, the roots of this culture and its interaction with the preceding EB III culture are still not fully understood.

The recent EB "High Chronology," which is based on a systematic analysis of ${ }^{14} \mathrm{C}$ dates obtained from EB sites in the Southern Levant, showed that EB III cities ceased to exist around 2500 BCE. Such observation extends the duration of the IBA period from about 300 years, as was the previous consensus, to about 500-600 years (Regev et al. 2012, 2014; Höflmayer et al. 2014), shifting more attention to the transition from the EB III to the IBA. Yet another current view is that the end of the EB III did not happen simultaneously everywhere and that there are cases, as in Jericho, where EB III ended later, around 2300 BCE (Nigro et al. 2019). Early IBA absolute radiocarbon $\left({ }^{14} \mathrm{C}\right)$ dates from around 2500

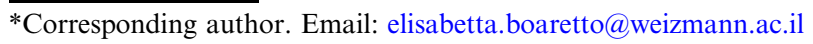




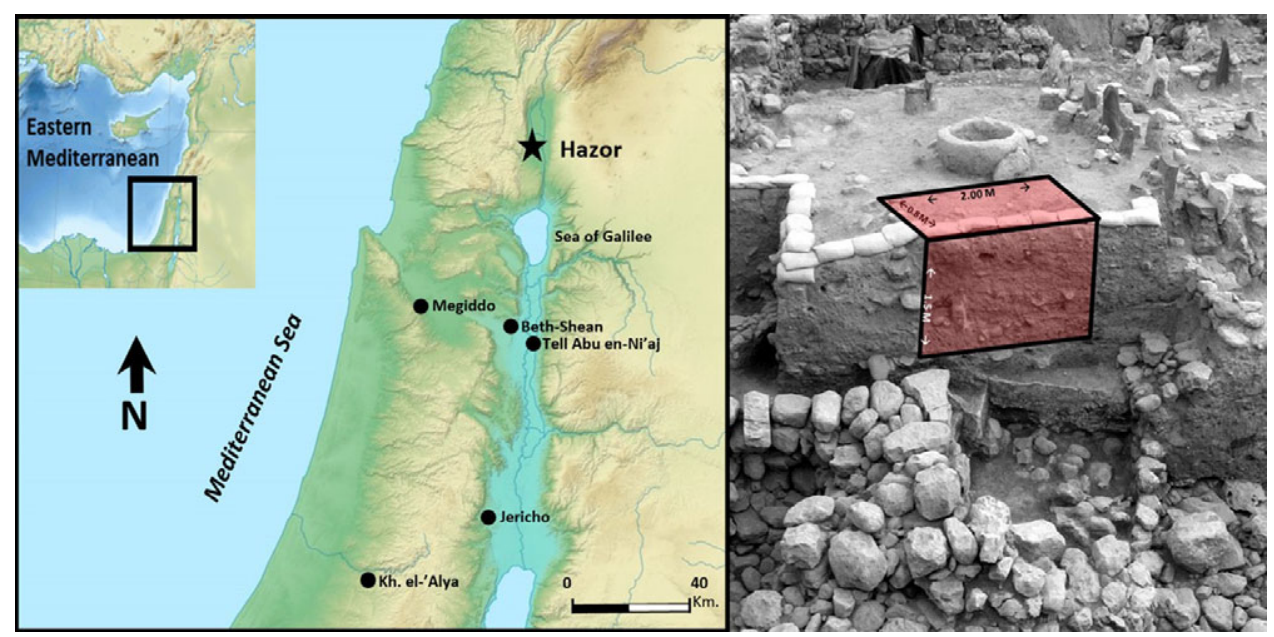

Figure 1 Left: Location of Tel Hazor and other sites with IBA remains mentioned in the paper. Right: Partial view of Area A on the acropolis of Tel Hazor before our probe excavation, looking north (after Zuckerman and Bechar 2017 Photo 1.6). Our probe excavation parameters are drawn on the photo.

BCE or even somewhat earlier have been published lately from short-lived samples from Tell Abu el-Niaj in Transjordan (Falconer and Fall 2019; Fall et al. 2020) and Khirbat el-'Alya in the Judean Shefelah region (Lev et al. 2020). Absolute dates between 2500 and 2300 have also been published lately from IBA contexts in the Negev (Dunseth et al. 2017). As stated above, most IBA settlements excavated to date in the southern Levant were established as new rural sites. Tel Hazor in the north of modern-day Israel (Figure 1) is one of the few sites where IBA architectural remains were found above the EB III city ruins (Bechar 2017a). Other such sites west of the Jordan River are Beth-Shean (Mazar 2006), Jericho (Nigro 2003), and possibly Megiddo (Adams 2017). In the later EB III stratum at Hazor (Stratum XIX) only a few sherds of the distinct pottery type Khirbet Kerak Ware, a type which is common in EB III phases of sites in northern Israel, were found. This stands in contrast to the earlier EBIII stratum (Stratum XX), where large amounts of sherds of this family were found (Ben-Tor 2017: 149), thus suggesting the existence of a late EB III phase (EB IIIB according to the Hazor excavators) in Stratum XIX at Hazor (Ben-Tor and Bechar 2017: 1, 3). The research questions to be tackled here are the following: (1) what is the date of the last phase of Hazor's EB III city? (2) What is the date of the IBA occupation above it? And (3) what is the chronological relationship between these two settlements? The excavators of Hazor proposed two scenarios in their discussion regarding the relationship between these two strata: either ... only a short occupational gap (if any) between the Early and Intermediate Bronze Age strata at Hazoror-an occupation gap of two or three centuries at Hazor. Of the two options-they favored only a short occupational gap, if any (Ben-Tor and Bechar 2017: 1). Our approach will complement the relative chronological considerations applied to date. This was done by locating and ${ }^{14} \mathrm{C}$ dating organic samples from representative contexts of the relevant strata at Hazor, in order to answer our research questions.

The Kimmel Center for Archaeological Science at the Weizmann Institute of Science conducted a small probe excavation at Tel Hazor during June 2017, in collaboration with 


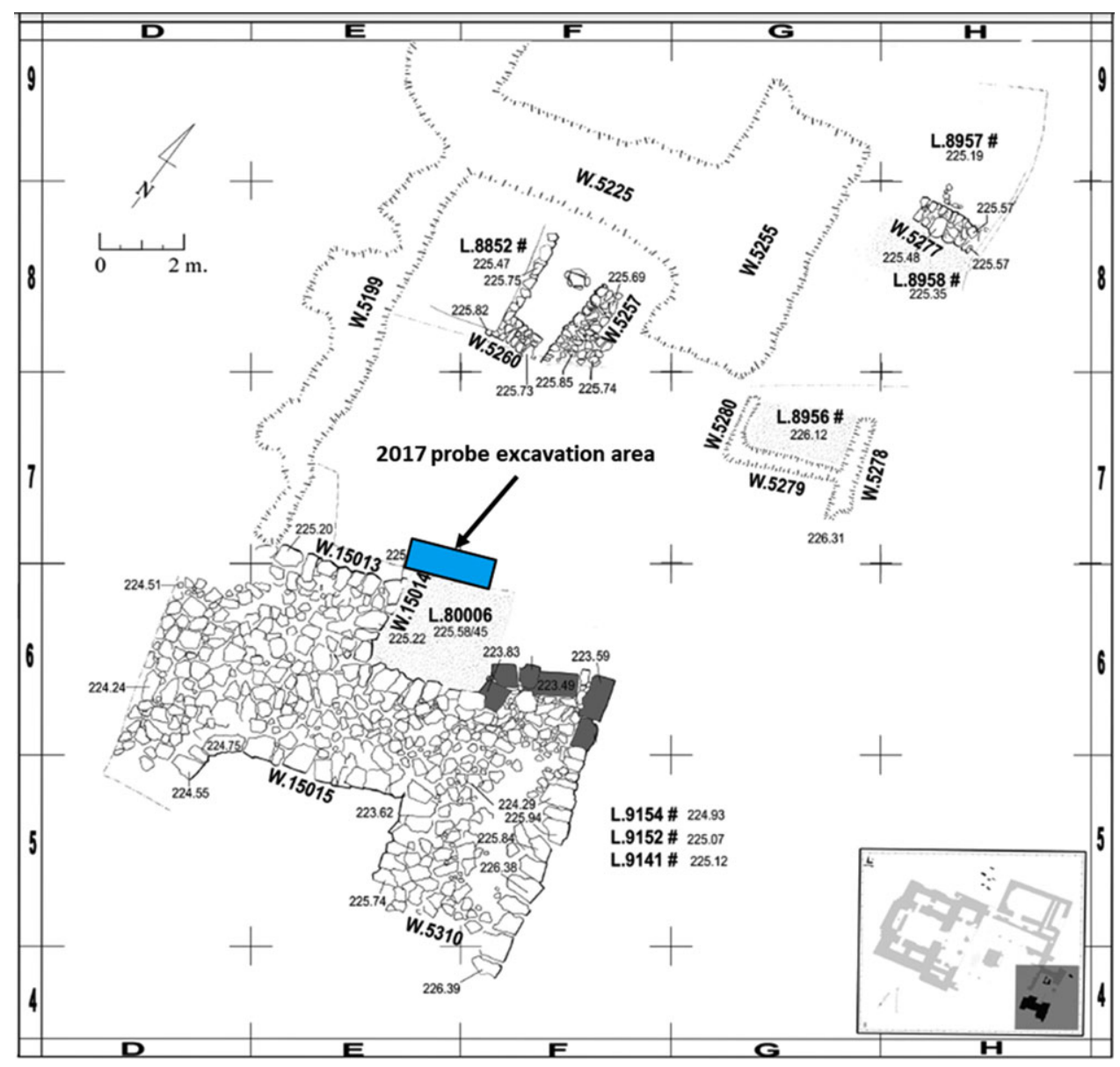

Figure 2 The parameters of the 2017 probe excavation marked in relation to the IBA remains, located in the southern part of the acropolis (after Bechar 2017a: Plan 2.2).

the directors of the Selz Foundation Hazor Excavations in Memory of Yigael Yadin (Hebrew University), Amnon Ben-Tor, and Shlomit Bechar. The location of this probe excavation was carefully chosen to collect samples that best represent both the last phase of the EB III city of Hazor and the IBA settlement above it. Locus L.80035 of the Hazor excavations is a representative context of the Stratum XIX, the last phase of the EB III city (Zuckerman and Bechar 2017: 9, Plan 1.2). According to its ceramic assemblage, this locus is contemporary with the other post Khirbet Kerak ware EB III contexts identified by Yadin's excavations at Hazor (Ben-Tor 2017: 149). Architectural remains from the IBA at Hazor were found solely by the renewed excavations. Locus L.80006 best represents Stratum XVIII, dated to the IBA. This locus is a plaster floor with multiple IBA vessels found in situ on it (Bechar 2017a: 14, 2017b: figs. 6.11, 6.12). The selected location for the probe excavation was a baulk in area A (the acropolis) that held the northern continuation of both L.800035 (Stratum XIX) and L.80006 (Stratum XVIII). Although our probe excavation covered only a small area $(2 \times 1 \mathrm{~m}$ wide and $1.5 \mathrm{~m}$ deep, see Figures 1,2$)$, it was able to reach wellexcavated contexts of Hazor excavations, dating to Stratum XIX and Stratum XVIII, precisely the contexts to be investigated within the framework of this study. 


\section{MATERIALS AND METHODS}

\section{Excavation Method}

The excavation was performed in layers of 5-10 cm. Each such layer was defined as a locus to allow high context analysis control. Particular contexts (installations, floors, stone accumulations) were assigned another separate locus. For each locus, multiple sediment samples were collected in plastic vials of $10 \mathrm{~mL}$ for later context analysis. Changes in color or consistency of the sediments were also recorded, and characteristic material was collected. When a conspicuous context was encountered (e.g., burnt material, pottery in articulation, plaster material), higher sampling resolution was performed to obtain an adequate record of that context. Charred remains were carefully searched for visually within in-situ sediments during excavation. Sediments estimated to contain potential in-situ charred remains were collected and dry-sifted in the field through a 2-mm mesh sieve to locate seeds, pits, and charcoal. The identified organic remains were documented and collected in aluminum foil envelopes. No wet sieving was performed as we have verified that wet sieving recovers less material than dry sieving in the type of sediment that was excavated, as some charred remains dissolved in the water.

\section{Radiocarbon Samples Context Characterization}

A microarchaeological approach was implemented during the excavation and sampling process to provide insight into the site-formation and post-depositional processes. This methodology enabled us to verify secure contexts for dating and to choose samples for ${ }^{14} \mathrm{C}$ dating that were burned or buried in situ. It allowed us to identify and exclude samples that may have been included in the archaeological context by post-depositional processes (e.g., bioturbation), or residual from earlier occupation levels (for examples of microarchaeological research see Boaretto 2015; Dunseth et al. 2016; Toffolo et al. 2012). The sediment samples that were collected during the excavation, and from around the excavated area as control, were analyzed to understand the sampled location context and its relation to its surroundings by using the following analytical methods:

- FTIR (Fourier transformed infrared spectroscopy)-Nicolet iS5 FTIR was used to explore the sample mineral composition and to identify anthropogenic features such as burnt clay and phosphates (Berna et al. 2007; Weiner 2010).

- Phytolith counts (number of phytoliths per $1 \mathrm{~g}$ of sediment)—were conducted to compare phytoliths abundance between the various locations and identify dominant vegetation types, using phytoliths extraction and quantification procedure (Katz et al. 2010).

- Microscopic examination-was done to further understand the sediment context by locating special inclusions such as calcium-oxalate pseudomorphs indicating ash remains and dung spherulites indicating the presence of dung or manure (Gur-Arieh et al. 2014; Dunseth et al. 2016).

Calcium-carbonate rich substances (especially when suspected as anthropogenic, e.g., floor, plaster, installation)—were analyzed with the FTIR-based "Grinding curve" method (Regev et al. 2010) to help determine their formation mechanism. Ceramic, flint, and stone artifacts were documented and collected for further processing as part of this research. The location, layout, and identification of such artifacts helped in understanding the context of the associated organic samples and to determine valid candidates for ${ }^{14} \mathrm{C}$ dating. 


\section{Preparation and Dating of Organic Samples}

Organic samples were examined and analyzed to determine their exact context, related material culture, and adjacent loci. Short-lived organic samples found in the same contexts as related material culture, and with unlikely intrusion from other layers, were regarded as candidates for ${ }^{14} \mathrm{C}$ dating of their contexts.

Charred samples were identified taxonomically using a Leica M80 binocular microscope at 10 $50 \times$ magnification. Charred samples chosen for dating were pretreated for removal of carbonates and humic substances using the ABA (acid-base-acid) protocol (Yizhaq et al. 2005; Rebollo et al. 2008). After pretreatment, charred material was analyzed by FTIR to verify the absence of clay and carbonates. Percent of efficiency of the pretreatment (eff.\%) was recorded as the ratio between the final weight after preparation and the initial weight of the sample.

Combustion and graphitization of pretreated botanic samples were done in the Kimmel Center for Archaeological Science at the Weizmann Institute of Science. The Hazor pretreated samples numbered up to RTD-9235 were combusted to $\mathrm{CO}_{2}$ in vacuumed quartz tubes with $200 \mathrm{mg}$ of copper oxide heated to $900^{\circ} \mathrm{C}$ for $200 \mathrm{~min}$. The $\mathrm{CO}_{2}$ was reduced to graphite using $2 \mathrm{mg}$ of iron as a catalyst and hydrogen, which was heated to $600^{\circ} \mathrm{C}$ for 20 $\mathrm{hr}$. The percentage of carbon in the pretreated material $(\mathrm{C} \%)$ was calculated from the $\mathrm{CO}_{2}$ pressure obtained after combustion and the amount of material used. Pretreated samples numbered from RTD-9844 and above were combusted and graphitized using the Vario Isotope Select Elemental Analyzer (EA), coupled with the AGE-3 graphitization system (Wacker et al. 2010) at the D-REAMS lab. Pretreated samples weighed in tin cups were dropped into the EA combustion tube, wherein the presence of external oxygen flash combustion occurred at a temperature of $950^{\circ} \mathrm{C} . \mathrm{CO}_{2}$ was separated from the rest of the gaseous combustion products and transferred by Helium carrier gas into the AGE-3 graphitization unit, where carbon was converted to graphite through reduction by hydrogen over iron as a catalyst.

The clean graphite ${ }^{14} \mathrm{C}$ content was measured by the D-REAMS accelerator (Regev et al. 2017). ${ }^{14} \mathrm{C}$ ages were reported in conventional radiocarbon years BP (Before Present, where "present" is defined as the year 1950) following international conventions (Stuiver and Polach 1977). All calculated ${ }^{14} \mathrm{C}$ ages have been corrected for the isotopic fractionation to be equivalent to the standard of $\delta^{13} \mathrm{C}$ value of $-25 \%$ (Stuiver and Polach 1977). The ${ }^{14} \mathrm{C}$ ages were calibrated using the OxCal 4.4 online version (https://c14.arch.ox.ac.uk/oxcal/ OxCal.html) and the IntCal20 calibration curve (Reimer et al. 2020). Bayesian probability modeling and related tools in OxCal v 4.4 (Bronk Ramsey 2009) were applied to the ${ }^{14} \mathrm{C}$ measurements using the sequence of the dated samples based on their stratigraphy to increase the precision of the calibrated results.

\section{RESULTS}

Figure 3 is a schematic section of the probe excavation, presenting the main features that were revealed within the excavation. Table 1 aligns between parallel contexts of the probe excavation and the Hazor excavations (Ben-Tor et al. 2017). The upper layer (loci L100 to L108) extending down approximately $80 \mathrm{~cm}$ contained sediment with sherds and charcoals but no architectural remains, of which the uppermost $30 \mathrm{~cm}$ (loci L100 to L103) included a high concentration of bones. Below this upper layer, an IBA plastered installation was 
Table 1 Parallel contexts of the Hazor excavations (Ben-Tor et al. 2017) and the 2017 probe excavation.

\begin{tabular}{lcc}
\hline & EB-III loci & IBA loci \\
\hline Hazor excavations & Stratum XIX & Stratum XVIII \\
& L80035 & L80006 \\
2017 probe excavation & L114, L117, L118 & L109-L113, \\
& & L115-L116 \\
\hline
\end{tabular}

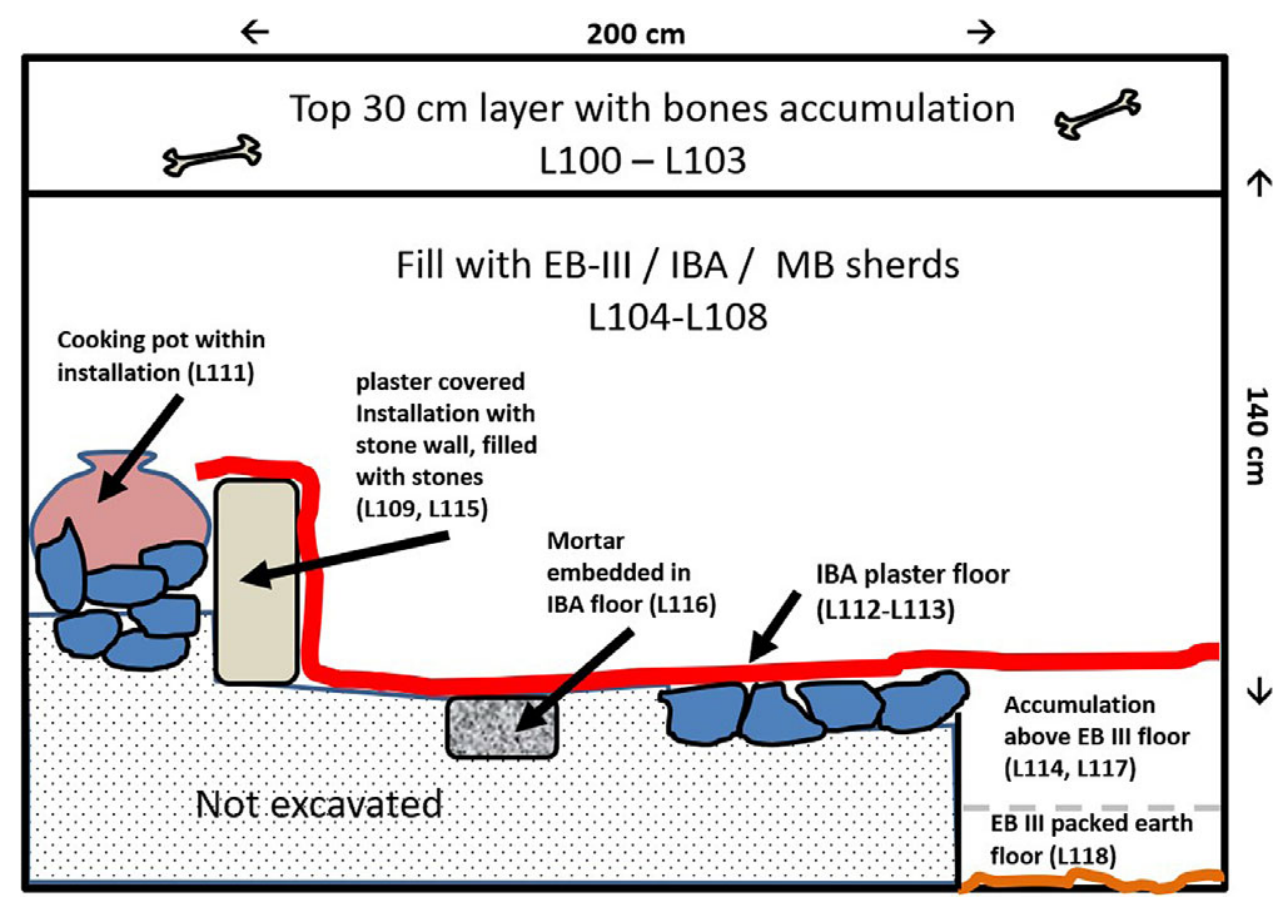

Figure 3 Schematic cross-section of the 2017 probe excavation at Hazor.

revealed. This installation was filled with cobblestones (L.109 on the higher layer and L.115 on the lower layer) and a complete IBA cooking pot (L.111). The globular hand-made cooking pot (Figure 4) can be ascribed to the IBA "Northern Family" (Dever 1980: fig. 2:4) and has parallels from Hazor and other IBA sites in Northern Israel (e.g., Bechar 2017b: Fig. 6.3:4,5,7; Eisenberg 2012: Fig. 44:1-3; Tadmor 1978: Fig. 5). Two samples from seed clusters between the installation cobblestones in L.109 and L.115 (RTD 9232 and RTD 9235, respectively) and an olive pit sample from within cooking pot L.111 (RTD 9233) were dated (Table 2).

A plaster floor (L.113) was found to the east of the installation, with a basalt mortar embedded in it (L.116, see Figure 5). The plaster floor was found at the elevation of IBA floor L.80006, attributed to Stratum XVIII. Floor L. 80006 abutted the baulk, which was excavated within the framework of this study (see Figure 2). The Hazor excavators did not unearth any architectural 

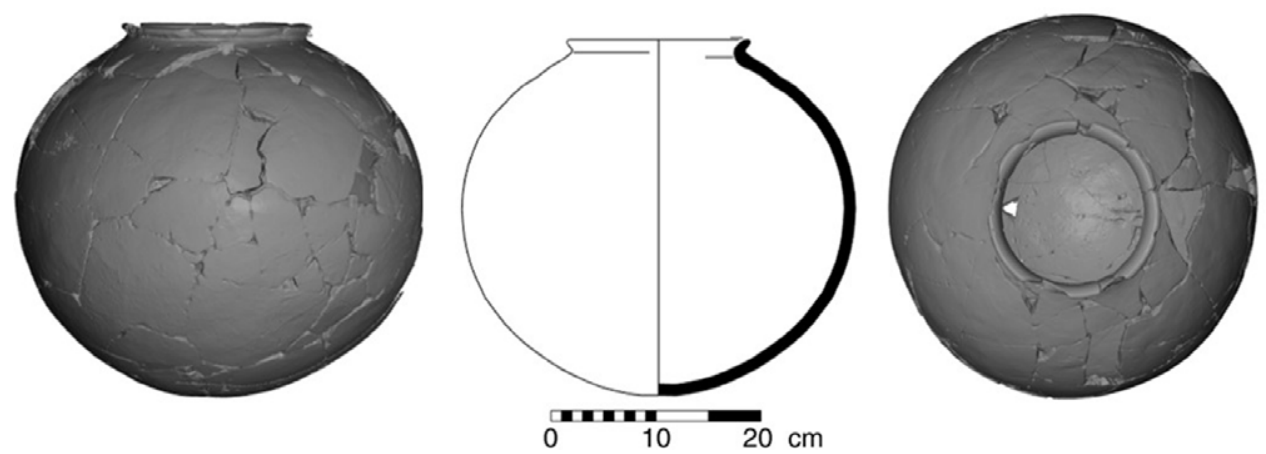

Figure 4 Cooking pot (L.111) that was found inside the IBA installation after restoration.



Figure 5 IBA excavated area in Tel Hazor 2017, looking north. IBA plastered installation with stones and embedded cooking pot on the left. Plaster floor L.113 of the IBA is on the right. Embedded mortar L.116 within the IBA floor is indicated by the red arrow. The scale bar is $50 \mathrm{~cm}$. The inset on the upper right corner shows the mortar after clearing it. Looking north (photo: Ron Lev).

remains on or above this floor, yet they have already noted the related installation in the baulk (Bechar 2017a: 14). Thus, floor L.113 is the northern continuation of floor L.80006. The plaster floor extended and covered the installation, creating a single unit. The plaster was analyzed (via FTIR "grinding curve" method) as packed powdered limestone. An olive pit sample found resting on floor L.113 (RTD 9234) and an olive pit sample found within mortar L.116 (RTD 9847) were dated (Table 2). A small plaster patch of a different texture on the installation wall indicates a mending operation (Figure 6). This unique plaster patch included charred straw temper, which was mechanically extracted from a plaster sample while being viewed with a binocular microscope in a sufficient amount for ${ }^{14} \mathrm{C}$ dating (Figure 7) and was dated (RTD 9845, Table 2). 


\begin{tabular}{|c|c|c|c|c|c|c|c|c|}
\hline \multicolumn{9}{|c|}{ cal treatment data of dated samples from the probe excavation. Samples are ordered according to stratigraphy } \\
\hline $\begin{array}{l}\text { Sample } \\
\text { number }\end{array}$ & Field ID & Context & $\begin{array}{l}\text { Dated charred } \\
\text { material }\end{array}$ & $\begin{array}{l}{ }^{14} \mathrm{C} \text { age } \\
\pm 1 \sigma \\
\text { year BP }\end{array}$ & $\begin{array}{l}\text { Calibrated range } \\
\pm 1 \sigma \mathrm{BC} \\
\text { (IntCal20) }\end{array}$ & $\begin{array}{l}\text { Calibrated range } \\
\pm 2 \sigma \mathrm{BC} \\
\text { (IntCal20) }\end{array}$ & $\begin{array}{l}\text { Eff. } \\
\%\end{array}$ & $\begin{array}{l}\mathrm{C} \\
\%\end{array}$ \\
\hline RTD-9844 & L104-B04 & Fill above IBA floor & Olea europaea seed & $3803 \pm 19$ & $\begin{array}{c}2285(37.0 \%) 2245 \\
2240(31.3 \%) 22200\end{array}$ & $\begin{array}{c}2295(83.9 \%) 2195 \\
2175\left(11.6^{\circ}\right) 2145\end{array}$ & 8.3 & 64.3 \\
\hline RTD-9231 & L106-B03 & Fill above IBA floor & Olea europaea seed & $3830 \pm 26$ & $\begin{array}{l}2340(8.5 \%) 23252305(20.2 \%) \\
22702260(39.6 \%) 2205\end{array}$ & $\begin{array}{l}2450(3.1 \%) 24202405 \\
\quad(5.8 \%) 23752350(84.4 \%) 2200 \\
2165 \\
(2.2 \%) 2150\end{array}$ & 52.0 & 93.0 \\
\hline RTD-9233 & L111-B15 & Charred surface inside cooking jar & Olea europaea seed & $3816 \pm 26$ & $2290(68.2 \%) 2205$ & $\begin{array}{l}2400(2.1 \%) 23852345(86.2 \%) \\
21952175(7.1 \%) 2145\end{array}$ & 25.6 & 56.0 \\
\hline RTD-9234 & L112-B03 & Ashy patch on IBA floor & Olea europaea seed & $3852 \pm 26$ & $\begin{array}{l}2405(10.7 \%) 23802345 \\
\quad(41.2 \%) \\
22802255\left(25.5^{\circ} \%\right) 2210\end{array}$ & $\begin{array}{l}2455(74.9 \%) 22752260(20.5 \%) \\
\quad 2205\end{array}$ & 41.2 & 67.7 \\
\hline RTD-9847 & L116-B10 & Seeds inside the mortar & Olea europaea seed & $3844 \pm 24$ & $\begin{array}{l}2395(1.6 \%) 2390 \\
2346(45.8 \%) 2276 \\
2252(21.2 \%) 2210\end{array}$ & $\begin{array}{l}2455(6.9 \%) 24202410(10.9 \%) 2375 \\
\quad 2360 \\
(77.7 \%) 2205\end{array}$ & 4.1 & 63.4 \\
\hline RTD-9845 & L112-B20 & Plaster temper & Straw & $3782 \pm 27$ & $\begin{array}{l}2280(23.8 \%) 2250 \\
2230(5.3 \%) 2220 \\
2210(12.1 \%) 2195 \\
2175(27.0 \%) 2145\end{array}$ & $\begin{array}{l}2295(93.6 \%) 2135 \\
2080(1.8 \%) 2060\end{array}$ & 5.1 & 57.7 \\
\hline RTD-9232 & L109-B12 & $\begin{array}{l}\text { Seeds cluster Between Installation } \\
\text { stones }\end{array}$ & Legumes & $3876 \pm 26$ & $\begin{array}{l}2450(17.9 \%) 24202405 \\
(18.7 \%) 23752355(31.7 \%) \\
2295\end{array}$ & $2465(93.1 \%) 22852250(2.4 \%) 2235$ & 3.7 & 62.0 \\
\hline RTD-9235 & L115-B04 & $\begin{array}{l}\text { Seeds cluster Between Installation } \\
\text { stones }\end{array}$ & Legumes & $3864 \pm 27$ & $\begin{array}{l}2450(13.5 \%) 24202405 \\
(15.8 \%) 23752350(38.9 \%) \\
2290\end{array}$ & $\begin{array}{l}2460(86.2 \%) 22802250(6.1 \%) 2230 \\
\quad 2220 \\
\quad(3.1 \%) 2210\end{array}$ & 31.0 & 64.0 \\
\hline RTD-9846 & L114-B04a & $\begin{array}{l}\text { Above EB-III floor } \\
\text { Str XIX }\end{array}$ & Olea europaea seed & $4192 \pm 19$ & $\begin{array}{l}2880(15.7 \%) 2865 \\
2805(42.8 \%) 2765 \\
2815(9.8 \%) 2705\end{array}$ & $\begin{array}{l}2890(24.3 \%) 2850 \\
2810(52.7 \%) 2745 \\
2730(18.0 \%) 2695\end{array}$ & 18.4 & 66.7 \\
\hline RTD-9236 & L118-B16 & $\begin{array}{l}\text { Seeds cluster on EB-III floor } \\
\text { Str XIX }\end{array}$ & Olea europaea seed & $4115 \pm 36$ & $\begin{array}{l}2850(19.3 \%) 28102745(8.7 \%) \\
27252700(34.0 \%) 2620 \\
2600(6.3 \%) 2585\end{array}$ & $\begin{array}{l}2870(25.6 \%) 28002780(69.9 \%) \\
\quad 2575\end{array}$ & 42.7 & 69.7 \\
\hline
\end{tabular}




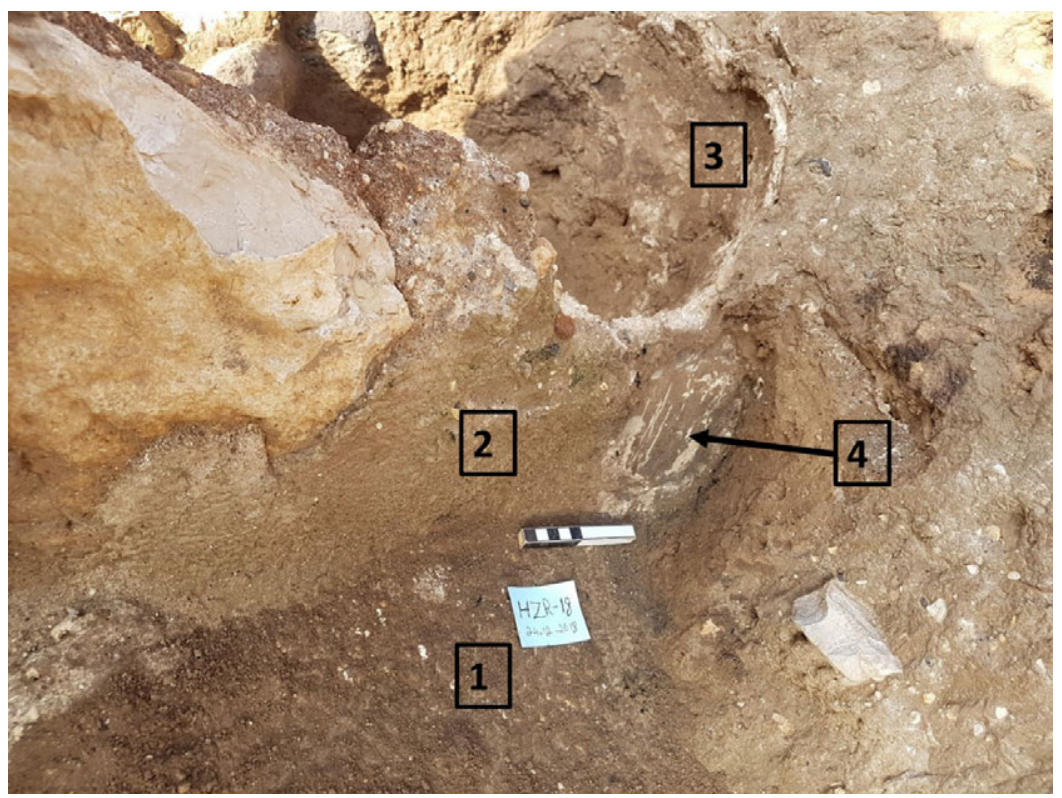

Figure 6 The IBA packed ground limestone "plaster" surfaces: (1) floor L.113; (2) plastered installation from the floor and up; (3) negative of the embedded cooking pot (L.111), after its removal; (4) patch with charred straw binders applied on the original installation "plaster." The scale bar is $10 \mathrm{~cm}$, looking northwest (photo: Ron Lev).



Figure 7 (a) cross-section of the plaster patch (L.112, B17) applied to the installation, showing charred material inserted within the plaster as temper; (b) charred material extracted for ${ }^{14} \mathrm{C}$ dating from L.112, B17 plaster patch matrix (photographs taken via binocular microscope Leica M80).

Excavations continued $40 \mathrm{~cm}$ below the IBA plastered floor L.113 (L.80006) on the eastern edge of the excavated area, through sediment accumulation with no architectural remains (L.114, L.117), and reached floor L.118, a packed earth floor with pottery sherds and a few clusters of charred seeds on it (Figure 8). Floor L.118 was found at the elevation of floor L.80035, attributed to Stratum XIX which was defined as EB IIIB post-Khirbet Kerak Ware phase (Ben-Tor and Bechar 2017: 3). Floor L.80035 is a packed earth floor covered by an ash layer, which continued into the excavated baulk and was associated with walls W.15011 and W.15012 located outside our probe excavation area (Zuckerman and Bechar 2017: 9, Pl. 1.2). Thus, floor L.118 is the northern continuation of floor L.80035. The concentration of phytoliths sampled from two contexts on floor L.118 was higher than in all other measured contexts in the probe excavation (Figures 9 and 10). FTIR analysis 


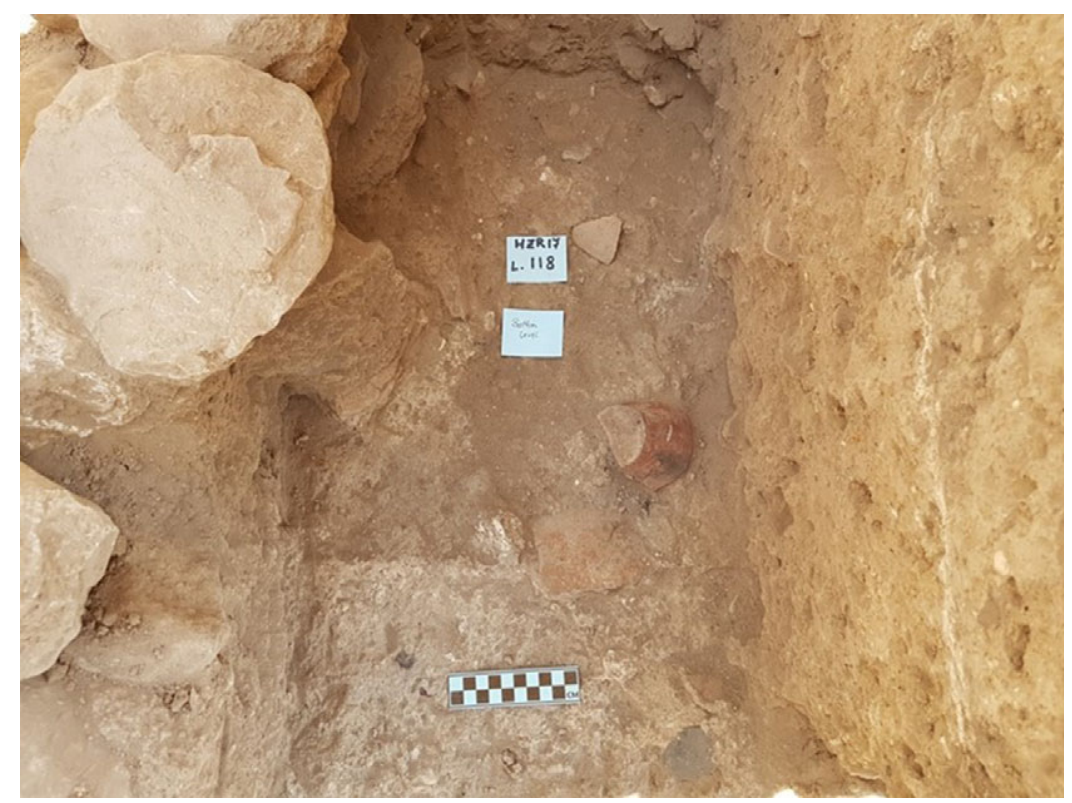

Figure 8 EB III floor (L.118). Note the IBA plaster floor line on the right baulk, about 40 $\mathrm{cm}$ above the EB III floor level. The scale bar is $10 \mathrm{~cm}$ (photo: Ron Lev).

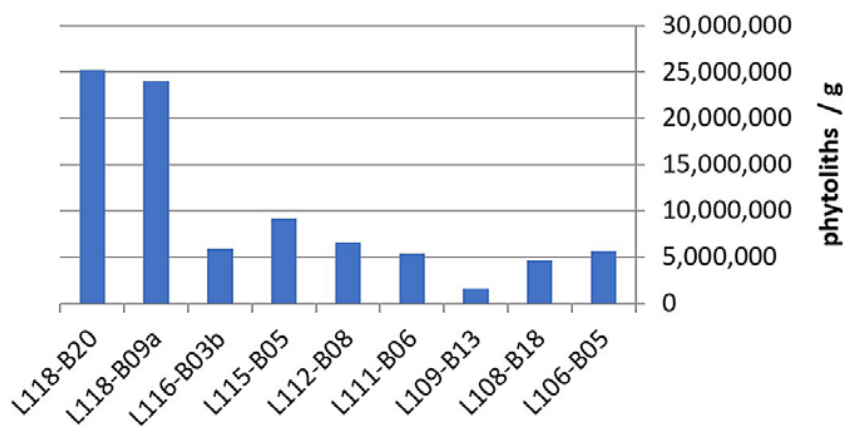

Figure 9 Phytoliths/g count in various contexts of the sampling probe excavation. The column labels show the locus and basket number. Note the high phytolith counts from L.118, the Stratum XIX EB III floor.

showed that the sediment in the vicinity of the clustered charred seeds was heated to $\sim 400^{\circ} \mathrm{C}$. In sum, the charred seeds cluster, its location directly on the floor, the adjacent heated sediment, and the concentrated deposition of phytoliths, are all proxies for in-situ context, making the short lived remains from L.118 excellent candidates for ${ }^{14} \mathrm{C}$ dating. Two samples, olive pits RTD 9836 and RTD 9246, from two EB III contexts (L.118 and L.114 respectively), were dated (Table 2).

All pottery sherds, bones, and flint remains were collected and documented within the probe excavation. Ten sherds of "Black Wheel-Made Ware" (henceforth BWMW), which is a distinct 


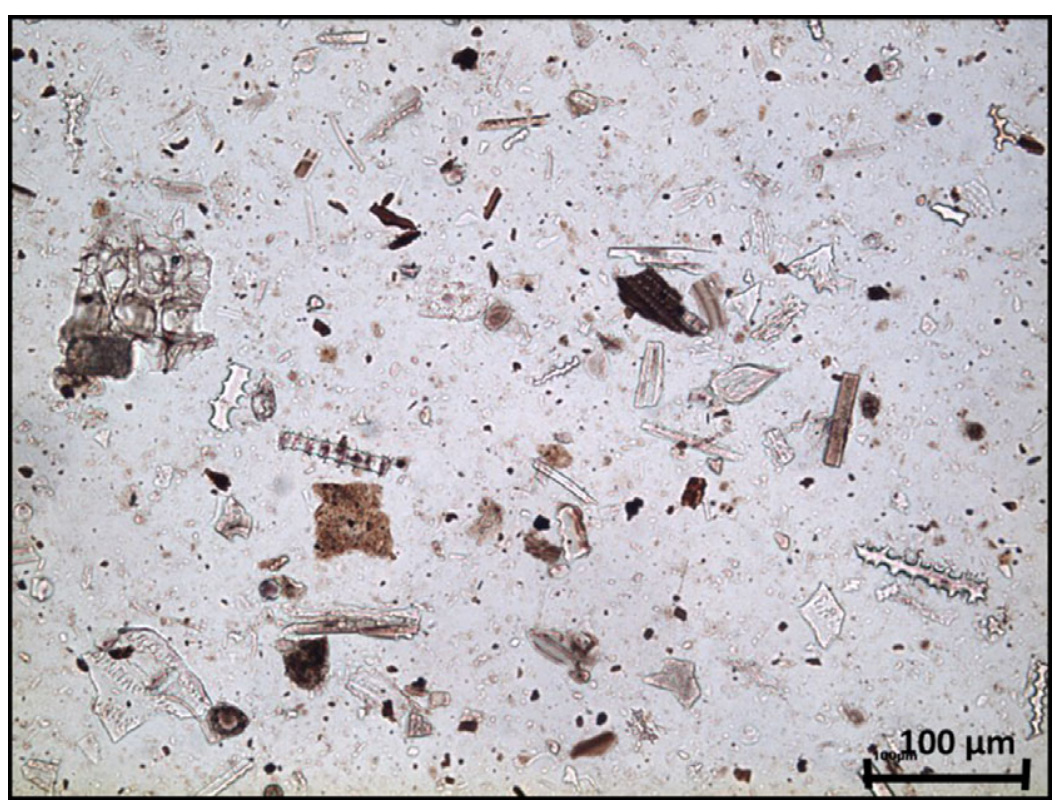

Figure 10 Microscopic view of phytoliths in sediment sampled on-top of packed earth floor L.118 (parallel to Stratum XIX floor L.80035).

type of IBA pottery found in northern Israel, Lebanon, and Syria (Bechar 2015), were found in the sediment layers up to $60 \mathrm{~cm}$ above the IBA plaster floor L.113.

In total, more than a hundred charred botanic samples were located and collected during the excavation, mainly seeds and charred wood above the floors and in the installation, but also from fill layers L.101 to L.108. Over one hundred sediment and plaster samples were collected and analyzed to support context determination. Charred samples were chosen to be dated based on their identification as short-lived remains, their location within the excavation stratigraphy, and analysis of their context (Figure 11). Two charred olive pit samples (RTD-9844 and RTD-9231) from the fill above the IBA architectural remains (L.106 and L.104, respectively) were also dated. The ${ }^{14} \mathrm{C}$ dates of the Hazor samples, together with the calibrated date ranges and the chemical details, are presented in Table 2 and Figure 12.

\section{Modeling of Hazor IBA Dated Samples}

Based on the stratigraphic relations between excavated contexts, Bayesian modeling was performed on relevant dated samples to define a probable range for each context. The two samples from the fill above the IBA floor, RTD-9231 (46 cm above the floor) and RTD9844 (65 $\mathrm{cm}$ above the floor), do not represent a secure context and were excluded from the modeling exercise. AMS ages from three separate contexts were included in our modeling:

- Context 1: Seeds found directly on the IBA floor, inside the mortar, and in the in-situ cooking pot (RTD-9234, RTD-9847, RTD 9233);

- Context 2: Charred straw within the plaster patch on the installation wall (RTD-9845); and

- Context 3: Seeds found between the cobblestones inside the installation (RTD-9232, RTD9235). 


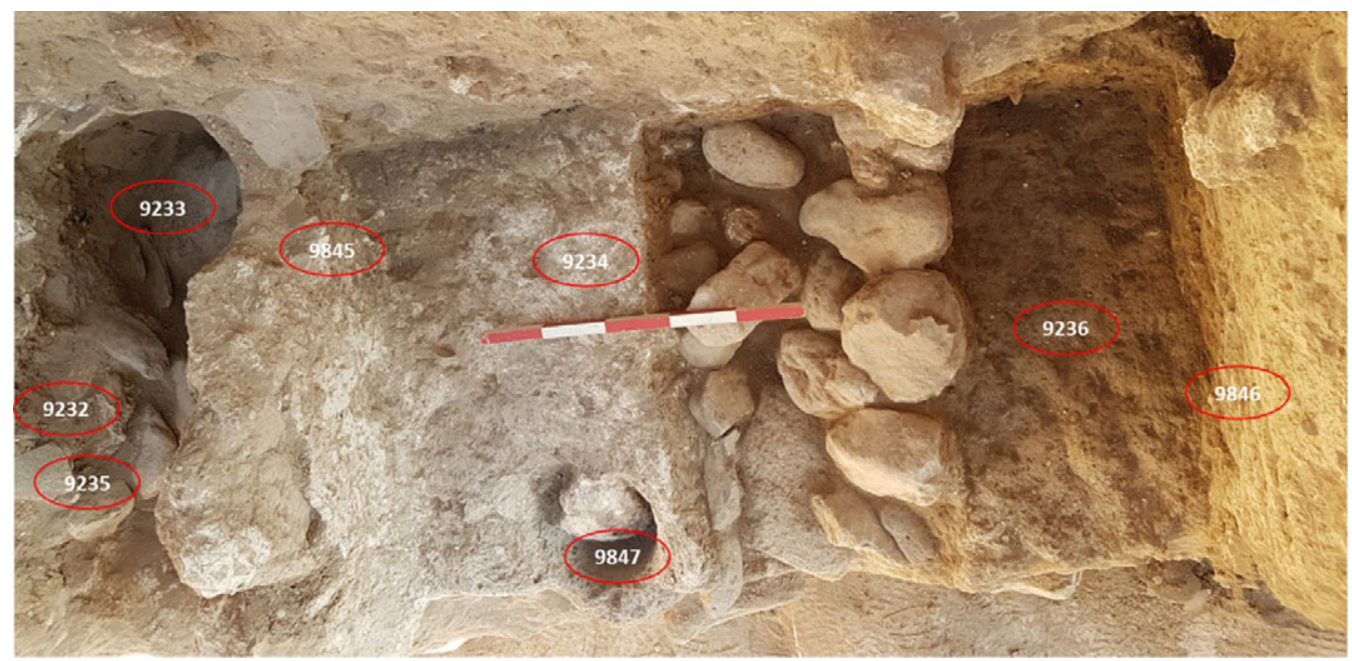

Figure 11 Find locations of dated samples marked by their lab number (circled in red). Samples RTD-9231 and RTD-9844 were found in the fill $46 \mathrm{~cm}$ and $65 \mathrm{~cm}$ respectively above the IBA floor L.113, and are therefore not presented here (photo: Ron Lev).

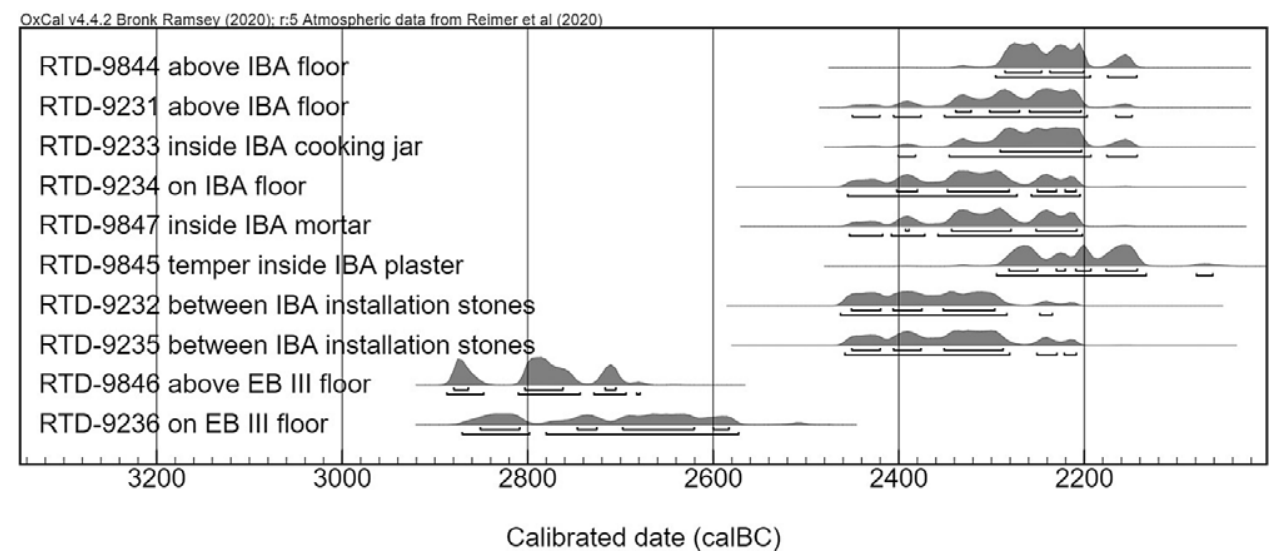

Figure 12 The unmodeled calibrated age probability distribution for charred seeds and straw samples from Hazor. Samples are ordered according to site stratigraphy (upper layer on top).

Samples from context 1 are stratigraphically located above the floor. They mark the end-use of the IBA floor and installation complex and are therefore later than contexts 2 and 3 . The stratigraphic order of context 2 and context 3 could not be clearly determined. Age modeling in which samples within the installation (context 3) are later than samples from the plaster patch (context 2) gave a lower than minimum model agreement (Amodel=35). The model in which the installation seeds (context 3) are earlier than the plaster patch (context 2) has a much stronger agreement value (Amodel=115) and was adopted (Table 3, Figure 13). This Bayesian modeling suggests the Hazor IBA occupation phase began in the second half of the 24th century BC and ended not later than $2200 \mathrm{BCE}(1 \sigma)$. The model's $2 \sigma$ range for the installation use (context 3) would push the suggested start 100 years 
Table 3 Bayesian modeling of ${ }^{14} \mathrm{C}$ dates from 3 sequential IBA contexts at Hazor.

\begin{tabular}{llcr}
\hline Context & Description & $\begin{array}{c}\text { Modeled calibrated } \\
\text { range } \mathrm{BC} \pm 1 \sigma\end{array}$ & $\begin{array}{c}\text { Modeled calibrated } \\
\text { range BC } \pm 2 \sigma\end{array}$ \\
\hline Context-1: & On IBA floor & $2255(68.2 \%) 2210$ & $2300(95.4 \%) 2200$ \\
RTD-9234 & (BWMW context) & & \\
RTD-9847 & & & \\
RTD 9233 & & $2290(68.2 \%) 2250$ & $2340(4.3 \%) 2325$ \\
Context-2: & Installation patch & & $2305(91.2 \%) 2220$ \\
RTD-9845 & & $2350(68.2 \%) 2285$ & $2440(92.4 \%) 2275$ \\
Context-3: & Inside installation & & $2250(3.0 \%) 2235$ \\
RTD-9232 & & & \\
RTD-9235 & & & \\
\hline
\end{tabular}

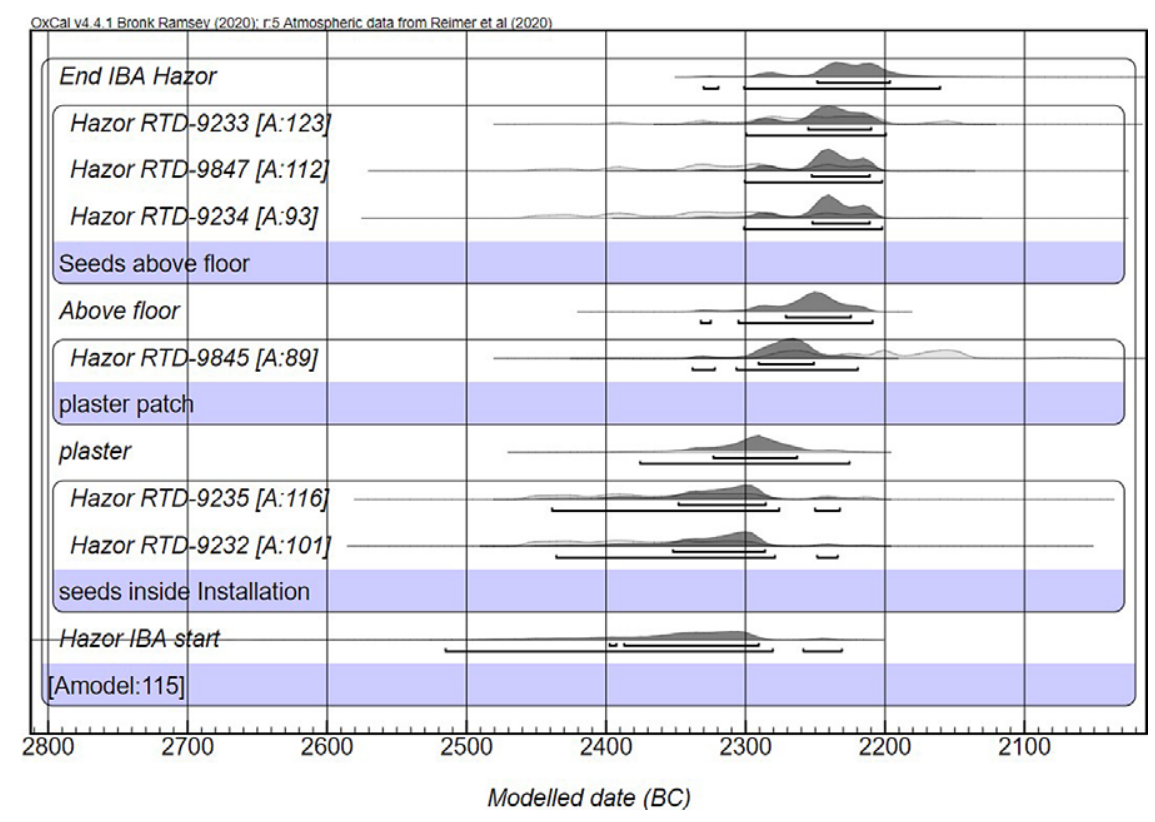

Figure 13 IBA sequential dating model of three phases (from earlier to later): 1-Seeds inside installation. 2-Plaster patch. 3-Seeds above the floor.

earlier, closer to the middle of the 25th century BCE, prolonging the IBA installation lifespan to be 100-200 years, as the installation patch (context 2) $2 \sigma$ date range starts around $2300 \mathrm{BC}$. The archaeological evidence for the IBA occupation at Hazor presents a single phase with scant remains, suggesting a shorter IBA occupation period.

\section{DISCUSSION}

Tel Hazor is one of the most important southern Levantine sites for IBA research as it holds substantial IBA remains directly above the ruins of its EB III city. The new ${ }^{14} \mathrm{C}$ dates obtained in this research clearly show a gap of over 100 years and probably more than 200 years between 
L.118 and L.112 (L.80035 and L.80006 respectively in Hazor excavations). The architecture of the IBA features revealed at Hazor is uniform, similar in nature, and is interpreted as being contemporaneous (Bechar 2017a: 18). Hazor excavators also identified floor L.80035 as belonging to the last phase of Hazor EB III city (Zuckerman and Bechar 2017: 9, 149). On this basis, we suggest that the dates presented here reflect a chronological gap between the end of the last EB III city (Stratum XIX) and the IBA settlement (Stratum XVIII) at Hazor (see Figure 12). Such a gap was assumed at two other southern Levantine sites west of the Jordan river: Beth-Shean, based on differences in the pottery assemblage (Mazar 2012: 28), and Jericho, based on stratigraphic observations (Nigro 2003: 131, 138). At Hazor, however, we now have clear ${ }^{14} \mathrm{C}$-based chronological evidence for a gap that probably extended over many decades, negating any direct relation between the new IBA settlement and the previous EB III city. The absolute date ranges of short-lived samples which were obtained from the post-Khirbet Kerak Ware phase of the EB III city at Hazor (RTD-9236 and RTD-9846 from L.80035, Stratum XIX) end by 2580 BCE, aligned with the "High Chronology" for the EBA in the southern Levant (Regev et al. 2012). The latest EB III phase in Beth-Shean, another major EB III city in the region, was also identified as a post Khirbet Kerak Ware phase: Stratum R-7a in Area R (Mazar 2012: 27). Recently published ${ }^{14} \mathrm{C}$ dates from Bet Yerah (RTT 5854 and RTT 5852), collected from the accumulation above an EB III period D floor (Regev et al. 2019: 69, table 2) are similar to the dates collected from the Stratum XIX floor of Hazor presented above. Assuming the post Khirbet Kerak Ware layers mark the last phase of EB III cities in the region before their demise, the new ${ }^{14} \mathrm{C}$ dates from Stratum XIX at Hazor suggest that the end of EB III cities in the Hula and Jordan Valleys is synchronized with that of other EB III cities in the southern Levant. The end of those cities was ${ }^{14} \mathrm{C}$ dated, and they all end by $2500 \mathrm{BCE}$, including Hebron, Numeira, Tel Yarmuth, Megiddo, and Tel es-Safi (Regev et al. 2012, 2014; Shai et al. 2014). The absolute dates of the IBA in Hazor have great chronological implications for the relative dating of IBA ceramic assemblages. Using these dates together with the rich ceramic assemblages published from Hazor (Bechar 2017b) will allow the identification of chronological anchors in the ceramic assemblages throughout the Hula Valley and beyond. Ceramic assemblages of the IBA are characterized by regional features (Dever 1980; D'Andrea 2014), but they are also known to have interregional ceramic traditions and similarities throughout the country. Therefore, the absolute dates of the Hazor assemblage will also have significant implications for the interpretation of assemblages found outside the Hula Valley. For example, the dated samples above the IBA floor were retrieved from the same context as BWMW sherds. The modeled date range of samples obtained from above the IBA floor provides us with an absolute timeframe for the presence of BWMW pottery vessels at Hazor: 2300-2200 BCE $(2 \sigma)$. This is a key date range for BWMW since Hazor has the largest assemblage of BWMW samples in the southern Levant (Bechar 2015). This timeframe indicates that BWMW vessels were in use at Hazor in the middle of the IBA, synchronous with the beginning of the EB IVB in the Northern Levant (D’Andrea 2018), where similar vessels appeared, e.g., in Byblus, Yabrud, and Tel Hizin (Bechar 2015).

\section{CONCLUSION}

This research was set to examine the absolute dates of the end of the EB III city at Hazor and the IBA settlement at the site. These dates were obtained within a probe excavation that was conducted at the site, adjoining previously excavated EB III and IBA floors. The dates suggest many decades of abandonment between the last EB III city phase and the rural IBA settlement 
established above it. The date of the latest EB III phase at Hazor is contemporary to the last phases of other EB III cities in the southern Levant. The dates obtained from the context above the IBA floor at Hazor presents a limited date range in the middle of the IBA and can help to refine the chronology of related IBA pottery types.

\section{ACKNOWLEDGMENTS}

The Exilarch Foundation supported the radiocarbon research for the Dangoor Research Accelerator Mass Spectrometer (D-REAMS) Laboratory. We wish to thank the Kimmel Center for Archaeological Science and George Schwartzman Fund for funding support to $\mathrm{RL}$, laboratory, and material analysis. EB is the incumbent of the Dangoor Professorial Chair of Archaeological Sciences at the Weizmann Institute of Science.

\section{REFERENCES}

Adams MJ. 2017. Egypt and the Levant in the Early/ Middle Bronze Age Transition. In: Hoflmayer F, editor. The Early/Middle Bronze Age Transition in the Ancient Near East: chronology, C14, and climate change. Chicago: The Oriental Institute. p. 493-515.

Bar S, Cohen O, Zertal A. 2013. New aspects of the Intermediate Bronze Age (IB/MBI/EBIV): Khirbet el-Meiyiteh-a fortified site on the eastern fringe of Samaria. Revue Biblique 120(2):161-181.

Bechar S. 2015. A reanalysis of the Black WheelMade Ware of the Intermediate Bronze Age. Tel Aviv 42(1):27-58.

Bechar S. 2017a. The Intermediate Bronze Age (Stratum XVIII. In: Ben-Tor A, Zuckerman S, Bechar S, Sandhaus D, editors. Hazor VIIThe 1990-2012 Excavations-The Bronze Age, Jerusalem. p. 14-19.

Bechar S. 2017b. The Intermediate Bronze Age Pottery. In: Ben-Tor A, Zuckerman S, Bechar S, Sandhaus D, editors. Hazor VII-The 19902012 excavations - the Bronze Age, Jerusalem. p. 161-198.

Ben-Tor A. 2017. Pottery from the Neolithic Period to the Early Bronze Age. In: Ben-Tor A, Zuckerman S, Bechar S, Sandhaus D, editors. Hazor VIIThe 1990-2012 excavations-the Bronze Age, Jerusalem. p. 147-160.

Ben-Tor A, Bechar S. 2017. Introduction. In: Ben-Tor A, Zuckerman S, Bechar S, Sandhaus D, editors. Hazor VII-The 1990-2012 excavations-the Bronze Age, Jerusalem. p. 1-3.

Ben-Tor A, Zuckerman S, Bechar S, Sandhaus D. 2017. Hazor VII-The 1990-2012 excavationsthe Bronze Age, Jerusalem. Hebrew University of Jerusalem, Israel Exploration Society.

Berna F, Behar A, Shahack-Gross R, et al. 2007. Sediments exposed to high temperatures: reconstructing pyrotechnological processes in Late Bronze and Iron Age Strata at Tel Dor (Israel). Journal of Archaeological Science 34(3): 358-373.
Boaretto E. 2015. Radiocarbon and the archaeological record: an integrative approach for building an absolute chronology for the Late Bronze and Iron Ages of Israel. Radiocarbon 57(2):207-216.

Bronk Ramsey C. 2009. Bayesian analysis of radiocarbon dates. Radiocarbon 51(1): 337-360.

Covello-Paran K. 2020. Excavations at Kfar Vradim and intraregional settlement patterns of the western Upper Galilee during the Intermediate Bronze Age. In: Richard S, editor. New horizons in the study of the Early Bronze III and Early Bronze IV of the Levant. Eisenbrauns. p. 376-394.

D'Andrea M. 2014. The Southern Levant in Early Bronze IV: issues and perspectives in the pottery evidence. Contributi e Materiali di Archeologia Orientale XVII,1, Vol. XVII. Rome.

D'Andrea M. 2018. The Early Bronze IVB pottery from Tell Mardikh/Ebla. Chrono-typological and technological data for framing the site within the regional context. Levant 1-29.

Dever WG. 1975. A Middle Bronze I cemetery at Khirbet el-Kirmil. In Eretz-Israel 12. p. 18*-33*.

Dever WG. 1980. New Vistas on the EB IV ("MB I") Horizon in Syria-Palestine. Bulletin of the American Schools of Oriental Research 237: 35-64.

Dever WG. 2014. Excavations at the Early Bronze IV Sites of Jebel Qa'aqir and Be'er Resisim, Winona Lake.

Dunseth ZC, Junge A, Fuchs M, Finkelstein I, Shahack-Gross R. 2016. Geoarchaeological Investigation at the Intermediate Bronze Age Negev Highlands Site of Mashabe Sade. Tel Aviv 43(1):43-75.

Dunseth ZC, Junge A, Lomax J, et al. 2017. Dating archaeological sites in an arid environment: a multi-method case study in the Negev Highlands, Israel. Journal of Arid Environments 144:156-169.

Eisenberg E. 2012. The Early Bronze Age IV site at Sha'ar Ha-Golan. Atiqot 69(1):1-73. 
Falconer SE, Fall PL. 2019. Early Bronze IV village life in the Jordan Valley- excavations at Tell Abu en-Ni'aj and Dhahret Umm el-Marar, Jordan. Oxford: BAR Publishing.

Fall PL, Falconer SE, Höflmayer F. 2020. New Bayesian radiocarbon models and ceramic chronologies for Early Bronze IV Tell Abu En$\mathrm{Ni}^{6} \mathrm{Aj}$ and Middle Bronze Age Tell El-Hayyat, Jordan. Radiocarbon 63(1):41-76.

Gur-Arieh S, Shahack-Gross R, Maeir AM, Lehmann G, Hitchcock LA, Boaretto E. 2014. The taphonomy and preservation of wood and dung ashes found in archaeological cooking installations: case studies from Iron Age Israel. Journal of Archaeological Science 46:50-67.

Höflmayer F, Dee MW, Genz H, Riehl S. 2014. Radiocarbon evidence for the Early Bronze Age Levant: the site of Tell Fadous-Kfarabida (Lebanon) and the End of the Early Bronze III Period. Radiocarbon 56(2):529-542.

Katz O, Cabanes D, Weiner S, Maeir AM, Boaretto E, Shahack-Gross R. 2010. Rapid phytolith extraction for analysis of phytolith concentrations and assemblages during an excavation: an application at Tell es-Safi/Gath, Israel. Journal of Archaeological Science 37(7):1557-1563.

Lev R, Shalev O, Paz Y, Regev J, Boaretto E. 2020. Bridging the Gap EBIII-IBA: Early Intermediate Bronze radiocarbon dates from Khirbat el-'Alya Northeast, Israel. Radiocarbon 62(6):1637-1649.

Mazar A. 2006. Tel Beth-Shean and the Fate of Mounds in the Intermediate Bronze Age. In: Gittin S, Wright JE, Dessel JP, editors. Confronting the past: archaeological and historical essays on ancient Israel in honor of William G. Dever. Winona Lake. p. 105-118.

Mazar A, editor. 2012. Excavations at Tel Beth-Shean, Volume IV: the fourth and third millennia BCE. Israel Exploration Society: Institute of Archaeology, Hebrew University of Jerusalem.

Nigro L. 2003. Tell es-Sultan in the Early Bronze Age IV (2300-2000 BC) Settlement vs Necropolis: a stratigraphic perspective. Conttribi e Materiali Di Archeologia Orientale IX. p. 1-38.

Nigro L, Calcagnile L, Yasin J, Gallo E, Quarta G. 2019. Jericho and the chronology of Palestine in the Early Bronze Age: a radiometric reassessment. Radiocarbon 61(1):211-241.

Oren ED. 1973. The Northern Cemetery of Beth Shan. Leiden: Brill.

Rebollo NR, Cohen-Ofri I, Popovitz-Biro R, et al. 2008. Structural characterization of charcoal exposed to high and low $\mathrm{Ph}$ : implications for ${ }^{14} \mathrm{C}$ sample preparation and charcoal preservation. Radiocarbon 50(2):289-307.

Regev J, de Miroschedji P, Greenberg R, Braun E, Greenhut Z, Boaretto E. 2012. Chronology of the Early Bronze Age in Southern Levant: new analysis for a high chronology. Radiocarbon 54(3-4):525-566.

Regev J, Finkelstein I, Adams MJ, Boaretto E. 2014. Wiggle-matched ${ }^{14} \mathrm{C}$ chronology of Early Bronze Megiddo and the synchronization of Egyptian and Levantine chronologies. Agypten Und Levante 24:243-266.

Regev J, Paz S, Greenberg R, Boaretto E. 2019. Radiocarbon chronology of the EB I-II and IIIII transitions at Tel Bet Yerah, and its implications for the nature of social change in the southern Levant. Levant 51(1):54-75.

Regev L, Poduska KM, Addadi L, Weiner S, Boaretto E. 2010. Distinguishing between calcites formed by different mechanisms using infrared spectrometry: archaeological applications. Journal of Archaeological Science. doi:10.1016/j.jas.2010.06.027.

Regev L, Steier P, Shachar Y, et al. 2017. D-REAMS: a new compact AMS system for radiocarbon measurements at the Weizmann Institute of Science, Rehovot, Israel. Radiocarbon 59(3): 775-784.

Reimer PJ, Austin WEN, Bard E, et al. 2020. The IntCal20 Northern Hemisphere radiocarbon age calibration curve (0-55 cal kBP). Radiocarbon 62(4):725-757.

Richard S. 2010. Khirbet Iskander: final report on the Early Bronze IV Area C "Gateway" and Cemeteries. Boston.

Richard S. 2020. New Vistas on the EB-IV of the Southern Levant-a case of "rural complexity" in the permanent sedentary sites. In: Richard $\mathrm{S}$, editor. New horizons in the study of the Early Bronze III and Early Bronze IV of the Levant. University Park (PA): Eisenbrauns. p. $417-53$.

Shai I, Greenfield HJ, Regev J, Boaretto E, EliyahuBehar A, Maeir AM. 2014. The Early Bronze Age remains at Tell es-Safi/Gath: an interim report. Tel Aviv 41(1):20-49.

Smithline H. 2002. An intermediate Bronze Age site at Horbat Qishron. In: Gal Z, editor. Eretz Zafon: studies in Galilean archaeology. Jerusalem. p. 21-46.

Stuiver M, Polach HA. 1977. Reporting of C-14 data: discussion. Radiocarbon 19(3):355-363.

Tadmor M. 1978. A Cult Cave of the Middle Bronze Age I near Qedesh. Israel Exploration Journal 28(1-2):1-30.

Toffolo M, Maeir A, Chadwick J, Boaretto E. 2012. Characterization of contexts for radiocarbon dating : results. Radiocarbon 54(3):371-390.

Wacker L, Nemec M, Bourquin J. 2010. A revolutionary graphitisation system: fully automated, compact and simple. Nuclear Instruments and Methods in Physics Research, Section B: Beam Interactions with Materials and Atoms 268(7-8): 931-934. 
Weiner S. 2010. Microarchaeology-beyond the visible archaeological record. New York.

Yannai E. 2016. 'En Esur ('Ein Asawir) II: excavations at the cemeteries. Jerusalem: Israel Antiquities Authority.

Yizhaq M, Mintz G, Cohen I, Khalaily H, Weiner S. 2005. Quality controlled radiocarbon dating of bones and charcoal. Radiocarbon 47(2): 193-206.

Zuckerman S, Bechar S. 2017. The Early Bronze Age. In: Ben-Tor A, Zuckerman S, Bechar S, Sandhaus D, editors. Hazor VII-the 1990-2012 excavations-the Bronze Age, Jerusalem. p. 7-13. 